\title{
Behavior of the Dry Bed Joint in the Mortarless Interlocking Masonry System: an Overview
}

\author{
Amin Al-Fakih, Bashar S Mohammed* and Mohd Shahir Liew \\ Department of Civil and Environmental Engineering, University Teknologi PETRONAS, Malaysia
}

Submission: January 21, 2018; Published: April 18, 2018

*Corresponding author: Bashar S Mohammed, Department of Civil and Environmental Engineering, University Teknologi PETRONAS, 32610 Seri Iskandar, Perak, Malaysia, Email: bashar.mohammed@utp.edu.my

\begin{abstract}
Interlocking mortarless masonry has numerous benefits over the conventional masonry due to its ease of construction and higher compressive strength by virtue of absence of mortar joints. Dry contacting surfaces between the blocks play a major role on the performance of dry stack masonry. In this paper, Dry joint surface characteristics and close-up deformation properties of interlocking dry stack blocks and bricks were reviewed as well as the dry joint opening. It was observed that the contact area increases with increasing of the compressive load. It's concluded that the behavior of the interlocking mortaless system is extremely affected by the behavior of the contact surface and the dry joint under compressive loading. Therefore, further research related to dry surfaces contact and interface closure and opening characteristics under compressive loads is needed.
\end{abstract}

Keywords: Interlocking; Masonry; Dry joint; Mortarless; Contact behavior

Abbreviations: MBTSS: Matrix Based Tactile Surface Sensors; DIC: Digital Image Correlation; ISEB: Interlocking Stabilized Earth Block

\section{Introduction}

In the past few decades, the concept of interlocking mortarless masonry unit has been widely increased in the field of civil engineering applications and construction practices due to its field productivity, efficiency and less skilled workers needed in the production and implementation [1]. One simple thing that absolutely contrasts interlocking bricks from conventional bricks is the mortar between bricks layers where mortar is not required for the construction of interlocking bricks. Due to that characteristic, the construction of masonry walls is faster and needs even unskilled workers as the bricks are arranged dry and interlock each other by the protrusions [2]. An assortment of interlocking bricks have been manufactured and produced during the last few years, varying in the composition of material, shape, size, strengths required, and usage needed, including Sparlock, Meccano, Sparfil, Haener, and Hydraform block system [3].

Due to the absence of mortar and the filling material between the masonry brick joints, the contact area need to be study with particular attention. The understanding of the compressive behavior of dry joints is a vital design parameter, for this reason only dry joint compressibility should be examined. Moreover, dry contacting surfaces between the blocks and bricks play a major role on the performance of dry stack masonry [4]. Thus, dry interfaces characterize the behavior of dry stack masonry under different loads. When the dry stack masonry is subjected to compression the interfaces gradually close and the surface contact area increases with the increment in loading $[5,6]$. However, very limited research outcomes are reported in the literature on the characterization of the dry interfaces under key loading conditions. In this paper, a review on the behavior of the contact area between interlocking bricks or blocks layers is presented.

\section{Dry Joint Closure}

Previous studies tests have been conducted to determine the behavior of contact area between brick layers and its effects on the overall behavior of masonry systems.

Greve et al. [7] have used matrix based tactile surface sensors (MBTSS) to determine the contact pressure and contact area of the dry stack joint subjected gradually to compression load normal to the dry interfaces. As MBTSS is an expensive, a cheaper carbon paper insert technique was also utilized to check its ability to trace surface contact area between the bricks subjected to compressive loading incrementally. The imprints obtained from the carbon paper were analyzed using Image J software that determined the contact area. The comparison between the two techniques revealed that the carbon paper 


\section{Civil Engineering Research Journal}

imprints significantly and consistently under-predicted the contact area. From the MBTSS data, it was concluded that the contact pressure and contact area increased gradually under the increase in loading. It was also observed that some high-pressure points existed within the contact surface and the location of the point remained unaffected throughout the loading history which demonstrated that the unevenness of the surface did not even out even at loads very close to the ultimate.

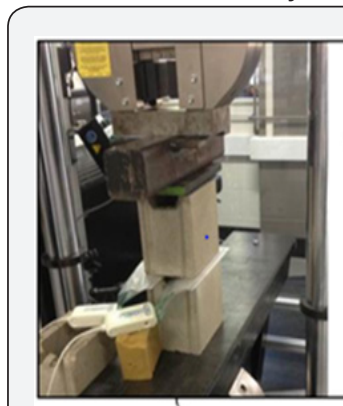

(a)

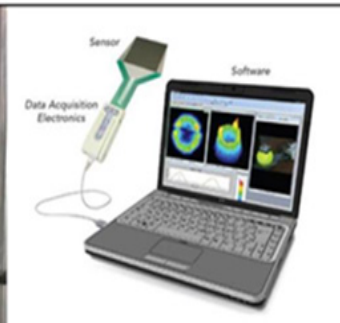

Figure 1: Testing of contact surfaces using MBTSS a) Test setup b) MBTSS system [4].

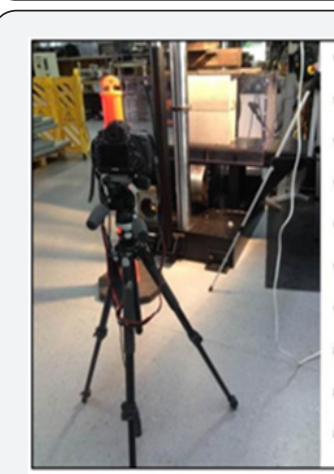

(a)

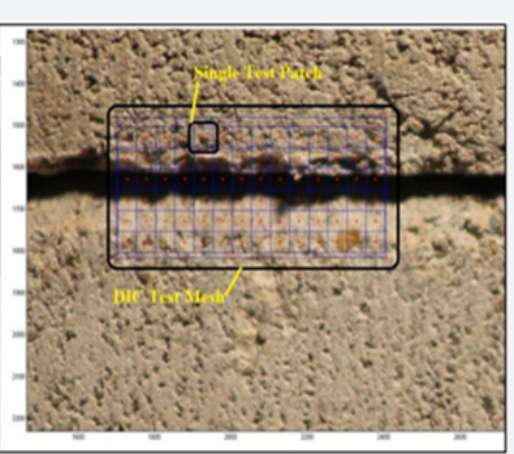

(b)
Figure 2: Surface strains measurement a) Test setup b) Typical test mesh for DIC analysis [4].

Zahra et al. [4] have experimentally examined the characteristics of the dry contacting surfaces of the concrete blocks and bricks. The contact surface area between two blocks under progressive compression load is determined by utilizing a matrix based tactile surface sensor positioned between the contacting surfaces of the two adjacent blocks. The tactile sensor determined both the contact area and the contact pressure distribution between the block surfaces as shown in Figure 1 . The contact surface area was found to be progressively increasing from about a minimum of $15 \%$ to a maximum of $95 \%$ of the net area with the progressive increase in compressive load. In addition, the closing deformation between the two surfaces under the compressive load was determined by a non-contact digital image correlation (DIC) technique as shown in Figure 2. Digital image correlation technique is extensively recognized for measuring surface strains in numerous laboratory testing including masonry $[8,9]$. The close-up joint deformations and strains were measured for bi-stacked masonry prisms. The test images were analyzed by a special program innovated by Willam
[9] to evaluate the strains in the area of the dry joint. It is found that the seating behavior of the dry interfaces in the early stage of compression is obvious through the gradually stiffening curve.

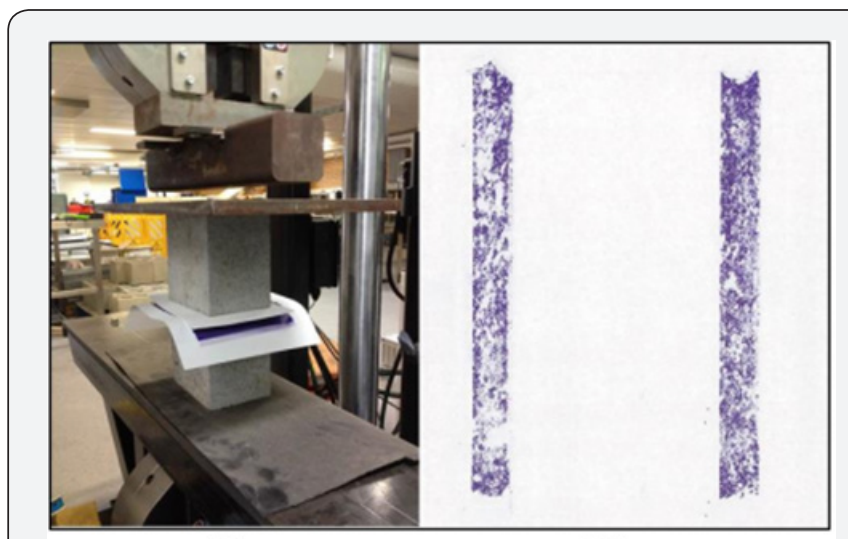

(a)

(b)

Figure 3: Test Setup a) sample with implanted carbon paper b) carbon paper traces [4].

The carbon paper image imprints were traced for loading increments of $20 \mathrm{kN}$ from $0 \mathrm{kN}$ to $100 \mathrm{kN}$ as shown in Figure 3. Each imprint was then analyzed by Image J software to determine the surface contact area. It can be observed that the contact area increases with increasing in the applied load. The area is increased from a minimum value to about $6500 \mathrm{~mm} 2$ $(82 \%)$ of the maximum contact area at $100 \mathrm{kN}$ for the half blocks,

Marzahn \& Konig [6] have examined the influence of the geometric imperfections in the bed joints to the structural behavior of mortarless masonry subjected to compressive loading. Results showed that the surface quality impacted the strength of brick units where the more irregular the bed planes the lower the strength because it causes initial deformation. However, the load bearing capacity was lowered by only 5 to $15 \%$ compared to mortared masonry due to the initial settlement.

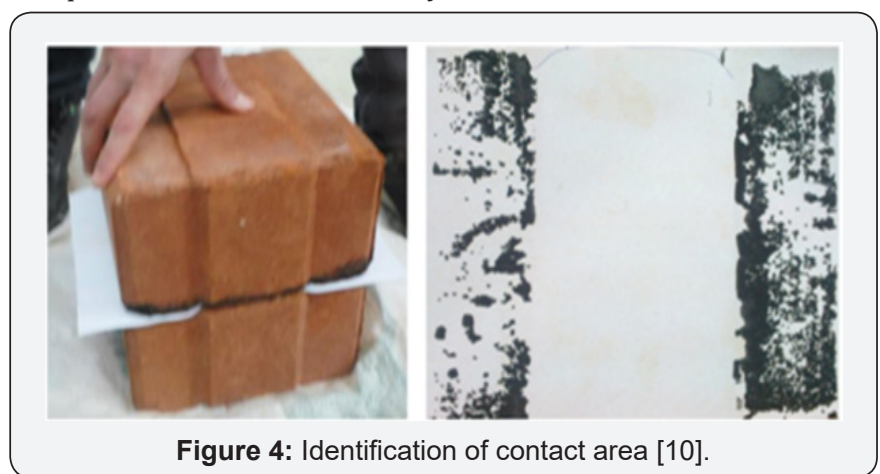

Ayed et al. [10] have used an image analysis method to determine the behavior of the dry stacked joint on the interlocking bricks. A plain white paper weighing $80 \mathrm{~g} / \mathrm{m}^{2}$ and free of physical or chemical effect on block has been used. The interface of the interlocking blocks was painted and the white paper between the blocks were placed in order to print the contact area as shown in Figure 4. An image analysis was developed on MATLAB in order to estimate the percentage of the 


\section{Civil Engineering Research Journal}

contact surface printed on the paper. It transformed the image of the printed paper in white and black pixels. Counting of pixels leads to the percentage of the contact area.

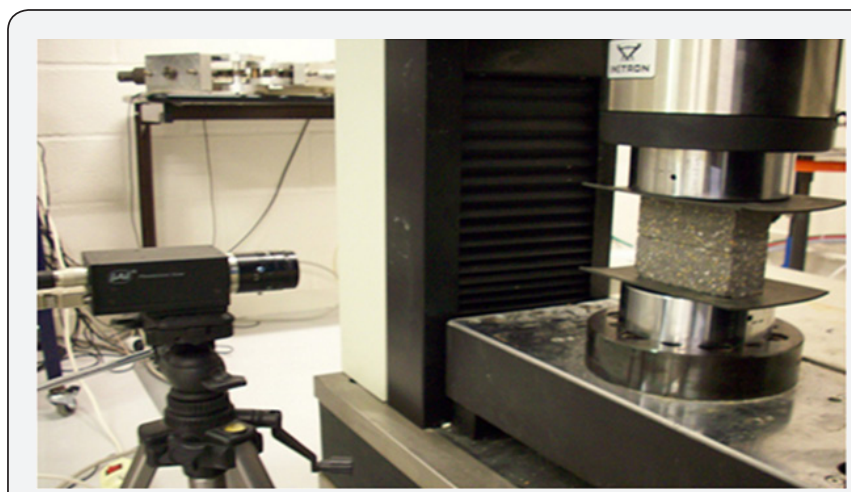

Figure 5: Experimental setup of compression test on dry joint brick [11].

Another recent study conducted by Rekik et al. [11] used Digital Image Correlation method to examine the compressibility of dry joints. Compressive tests on specimens that cut from Magnesia-Carbon mortarless bricks were carried out. Tests were conducted using a load cell of $200 \mathrm{kN}$ as shown in Figure 5 with an accuracy of $0.2 \%$ of the attained load and $0.033 \mathrm{~mm} /$ min displacement rate. 2D Digital Image Correlation is utilized to measure the compressive behavior of the dry joint.

Similarly, Andreev et al. [5] have investigated the dry joint closure behavior of refractory bricks under compressive loading. Finally, the procedure of joint closure was estimated in a roundabout way by stressing specimens with and without joints in wide temperature extend.

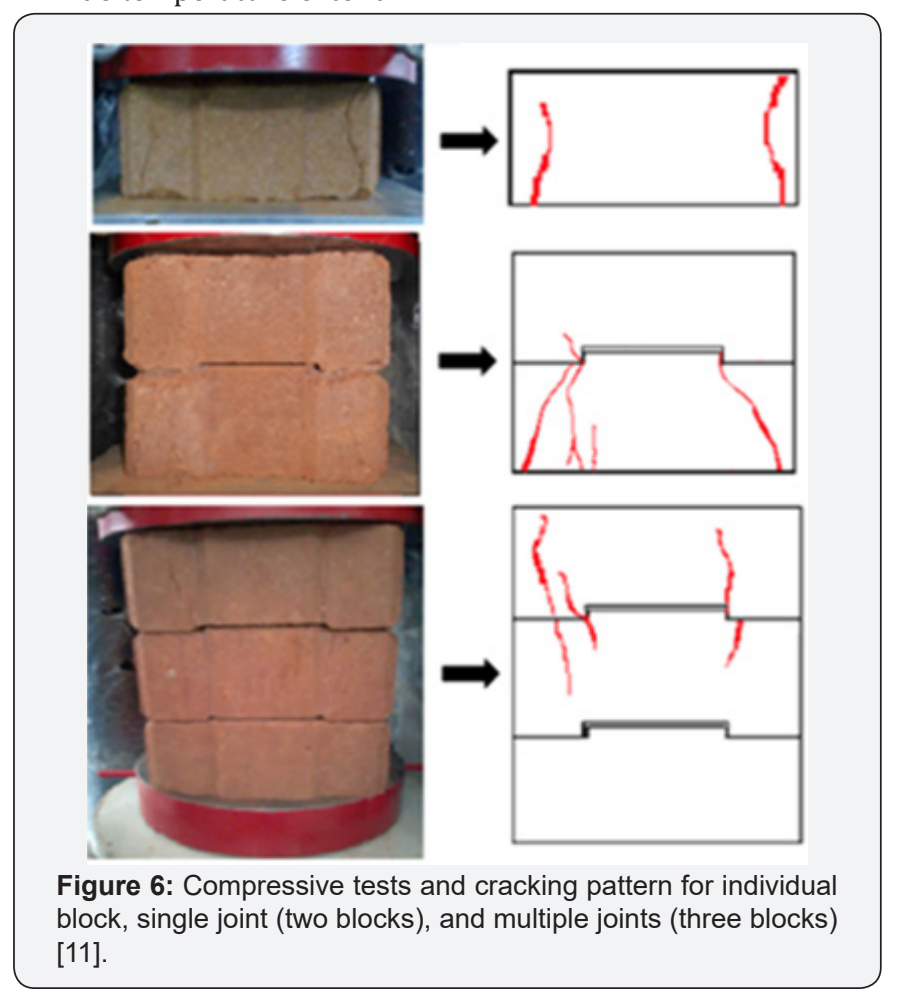

Ayed et al. [10] have analyzed the effect of contact area and the clearance between the blocks on the mechanical behavior of interlocking stabilized earth block (ISEB). The ISEBs were placed dry without grouting and tested under compression load tests to the mechanical behavior and the contact area effects, while the effect of the local stress around the clearance were performed by finite element modeling. The ISEB manufactured by red earth, sand, and 8 percent of cement. The compressive tests were conducted on individual block, single joint which consists of two interlocking blocks, and multiple joints that consists of three interlocking blocks as shown in Figure 6. As a result, the compressive strength for individual block, two blocks, and three blocks were $11.9 \mathrm{MPa}, 8.2 \mathrm{MPa}$, and $5.5 \mathrm{MPa}$, respectively. That means the contact area and the clearance between the blocks have an effect on the masonry compressive strength, causing it to decrease.

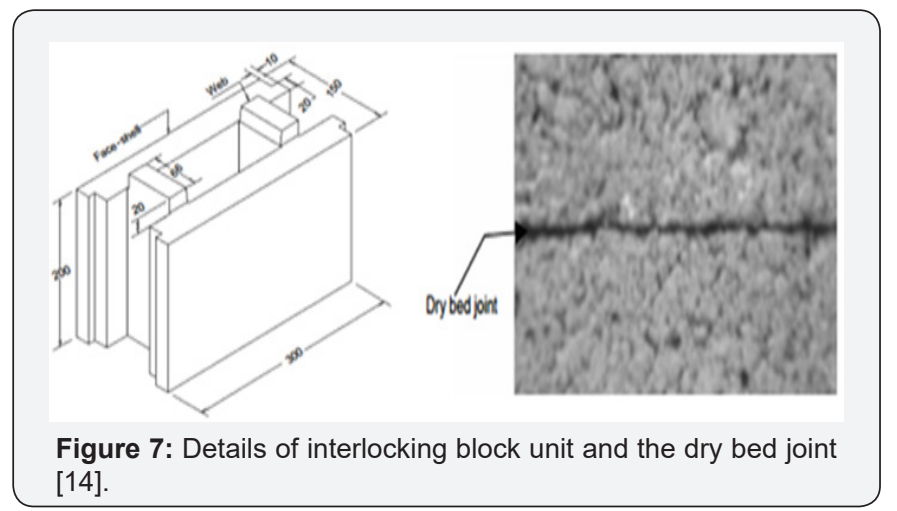

Jaafar et al. have investigated the behavior of the dry joints of interlocking masonry under compressive loading and consequently their impacts on the structural behavior of the interlocking mortarless hollow blocks for grouted and ungrouted prisms subjected to compression as shown in Figure 7. Two test setups are experimentally proposed to determine the contact behavior of dry joints with consideration of the geometric imperfections in the contacting interfaces. Results revealed that the geometric imperfections of the brick beds are highly affected the dry joint behavior and hollow prism deformation. Varied deformation forms are observed in mortarless un-grouted and grouted prisms. However, this behavior isn't common in grouted prisms, for the reason that visible deformation begins after 38\% of the maxim loading. Besides, the differences of strength and deformation in grouted samples are reduced in compression with those in un-grouted samples.

\section{Dry Joint Opening}

Studies stated that opening mechanism of wall specimens may be explained by arching mechanism in out-of plane wall. When a wall is subjected to load that is perpendicular direction to wall face, the wall will deflect in the out-of-plane direction (same direction where load applied). In mortarless construction, the wall tends to create an opening between courses where the location of maximum bending moment occurs. Opening 
mechanism in dry joint is related to the arching behavior during out-of-plane loading. Resistance of hollow masonry walls to out-of-plane loads can be increased by imposing large in-plane compression forces that can be induced when the wall is rigidly supported [12]. With increasing loading, flexural opening occurs at mid span. With the increased load, the wall is hard-pressed against the un-yielded supports producing clamping forces ( ) at the ends as shown in Figure 8.

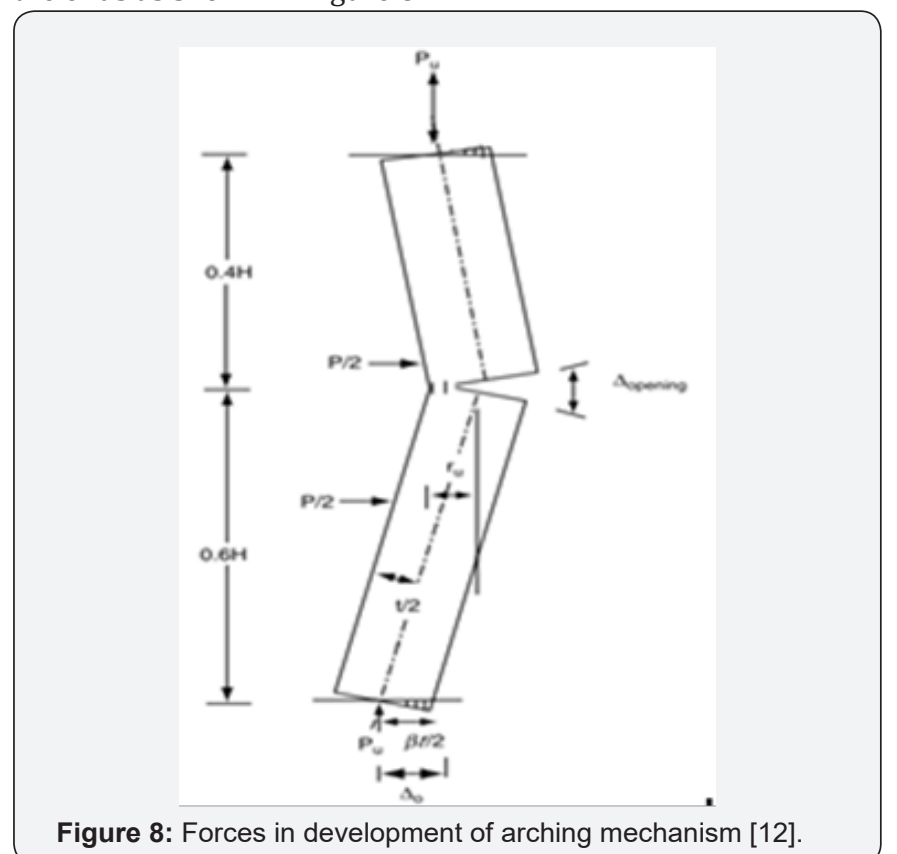

Three hinged arches reshaped where the external moment is resisted by the internal couple $\left(P_{u} * r_{u}\right)$ where $r_{u}$ is the arch height. The clamping force $P_{u}$ is a function of dry joint and contact area. The arch height $\left(r_{u}\right)$ is a function of the wall geometry, contact area $(\beta t / 2)$ and deflection $(\Delta o . \beta)$ is a slope of the bottom course opening, where $(t)$ is the wall thickness. Therefore, the more the wall deflects, the lower the clamping force $P_{u}$ due to the reduction of contact area and thus decreasing of resulting moment.

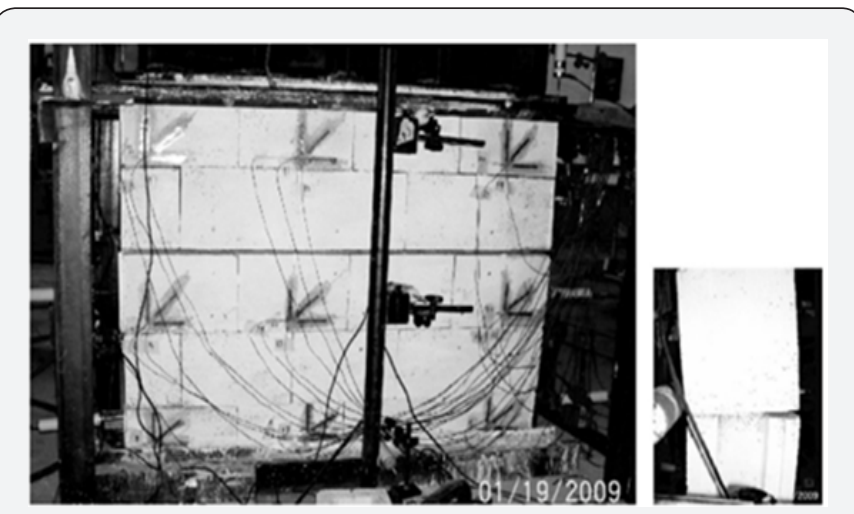

Figure 9: Opening of middle courses of wall during testing [13].

Safiee et al. [13] have examined the dry joint opening of interlocking mortarless wall subject to out-of-plane load. During testing, the dry joint opening mechanism around mid-height of wall, as shown in Figure 9, was dominated. The opening was measured by Demec points at several locations along the wall surface. The opening of middle courses of wall increased as lateral load increased for all series of specimens. The total opening may be affected by both lateral load and higher precompressive load. The study exhibited that the opening size was higher even at lower load. However for the partially grouted walls, the opening value was relatively limited and mostly occurred at higher lateral load.

\section{Discussion and Conclusion}

Dry joint surface characteristics and close-up deformation properties of interlocking dry stack blocks and bricks were reviewed in this study as well as the dry joint opening. It's found that the carbon paper image analysis method is unsuitable to determine the contact area between the block surfaces accurately. Meanwhile, the tactile sensors system computes the surface contact area consistently and reliably. It has been concluded that the contact surface of the mortar less masonry bricks on initially remained negligible due to the initial gap and voids between the blocks and undulations on the dry joint surface. After certain amount of time the contact area increased with a steep slope until it stabilized. Moreover, through the image analysis of contact prints, it was shown that the contacting areas increase with the increasing of the compressive load. The behavior of the interlocking mortar less system is extremely affected by the behavior of the contact surface and the dry joint under compressive loading. The geometric imperfections of the bed interlocking blocks and bricks were found to be a significant factors impacts the structural behavior of the mortar less masonry system. Finally, for increasing the acceptance of dry stack masonry system, further research related to dry surfaces contact and interface closure and opening characteristics under compressive loads is needed.

\section{References}

1. Edwards J, Gayed M, Pyra M, Rodriguez T (2010) Design and Construction of Interlocking Mortarless Block Masonry. Paper presented at the $2^{\text {nd }}$ MASONRY MINI SYMPOSIUM EDMONTON, ALBERTA.

2. Irwan J, Zamer $M$, Othman N (2016) A Review on Interlocking Compressed Earth Blocks (ICEB) with Addition of Bacteria. Paper presented at the MATEC Web of Conferences.

3. Anand K, Ramamurthy K (2005) Development and evaluation of hollow concrete interlocking block masonry system. Masonry Soc J 23(1): 11-19.

4. Zahra T, Yin Z, Dhanasekar M (2016) Experimental Investigation of Dry Joint Surface and Closure Characteristics of Interlocking Blocks under Compression. Paper presented at the $16^{\text {th }}$ International Brick and Block Masonry Conference (IBMaC-2016), Padova, Itlay.

5. Andreev K, Sinnema S, Rekik A, Allaoui S, Blond E, et al. (2012) Compressive behaviour of dry joints in refractory ceramic masonry. Constr Build Mater 34: 402-408.

6. Marzahn G, König G (2002) Experimental investigation of long-term behavior of dry-stacked masonry. Journal of The Masonry Society 12: 9-21. 


\section{Civil Engineering Research Journal}

7. Greve MJ, Rapp CT, Edwards JR, Barkan CPL, Wilson B (2013) Quantification of concrete sleeper and elastic fastening system demands utilizing concrete sleeper rail seat contact area. Paper presented at the Proceedings of the World Congress on Railway Research 2013 (WCRR 2013), Sydney, Australia.

8. Tung SH, Shih MH, Sung WP (2008) Development of digital image correlation method to analyse crack variations of masonry wall Sadhana 33(6): 767-779.

9. Willam K, Mohammadipour A, Mousavi R, Ayoub AS (2013) Failure of unreinforced masonry under compression. Paper presented at the Structures Congress 2013: Bridging Your Passion with Your Profession.

10. Ayed HB, Limam O, Aidi M, Jelidi A (2016) Experimental and numerical study of Interlocking Stabilized Earth Blocks mechanical behavior. J Build Eng 7: 207-216.
11. Rekik A, Allaoui S, Gasser A, Blond E, Andreev K, et al. (2015) Experiments and nonlinear homogenization sustaining mean-field theories for refractory mortarless masonry: The classical secant procedure and its improved variants. Eur J Mech A Solids 49: 67-81.

12. Drysdale RG, Hamid AA, Baker LR (1994) Masonry structures: behavior and design: Prentice Hall.

13. Safiee NA, Jaafar MS, Alwathaf AH, Noorzaei J, Abdulkadir MR (2011) Structural behavior of mortarless interlocking load bearing hollow block wall panel under out-of-plane loading. Adv Stru Eng 14(6): 1185-1196.

14. Jaafar M, Alwathaf A, Thanoon W, Noorzaei J, Abdulkadir M (2006) Behaviour of interlocking mortarless block masonry. Constr Mater 159(3): 111-118.

Your next submission with Juniper Publishers will reach you the below assets

- Quality Editorial service

- Swift Peer Review

- Reprints availability

- E-prints Service

- Manuscript Podcast for convenient understanding

- Global attainment for your research

- Manuscript accessibility in different formats

( Pdf, E-pub, Full Text, Audio)

- Unceasing customer service

Track the below URL for one-step submission https://juniperpublishers.com/online-submission.php 